\title{
The Prognostic Value of Renin in Critically Ill Patients on Mechanical Ventilator
}

\author{
HEBA YEHIA, M.Sc.; HOSSAM MOWAFY, M.D.; HAZEM EL AKABAWY, M.D.; \\ AHMED SAMIR, M.D. and ADEL ELSISI, M.D.
}

The Department of Critical Care, Faculty of Medicine, Cairo University

\begin{abstract}
Background: Mechanical ventilation can be lifesaving but it is also associated with numerous complications. The incidence of some complications increases with duration of mechanical ventilation, its effects on renal function results in decreas GFR, and fluid retention.

Aim of Study: To investigate the effect of positive pressure mechanical ventilator on renin and to study its prognostic value.

Patients and Methods: This study was conducted on 50 patients admitted to the intensive care unit (ICU) and needed mechanical ventilation and did not met any of exclusion criteria and 25 control (critically ill patients who did not need mechanical ventilator). The patients were divided into 2 equal groups; group I with use high PEEP (10-15) and group II with physiological PEEP (3-5). Renin levels were measured for these patients on first day of using PPV (renin 1) then after $72 \mathrm{~h}($ renin 2$)$.
\end{abstract}

Results: Renin levels were increased with use mechanical ventilation and were significantly higher with higher level of PEEP. There was correlation between renin with urea and Creatinine levels and significant correlation with APACH IV score and length of mechanical ventilation only in patients. Renin levels were significant higher in patients need hemodynamic support and in non survivors. We estimated an optimal cutoff values for renin 1 and renin 2 level of $(41,51 \mu \mathrm{g} / \mathrm{L}$ respectively) to predict ICU mortality with moderate sensitivity and specificity.

Conclusion: Mechanical ventilation caused elevation of renin levels especially with higher levels of PEEP. Renin levels in mechanically ventilated patients correlated with kidney function test (urea and Creatinine) and with length of mechanical ventilation and with APACH IV score. Values for renin 1 and renin 2 of $(41,51 / \mathrm{g} / \mathbf{A}$ respectively) could be used as a cutoff value to predict ICU mortality with moderate sensitivity and specificity.

Key Words: PPV-Renin-Mechanical ventilation - Neurohormonal pathway.

Correspondence to: Dr. Heba Yehia, The Department of Critical Care, Faculty of Medicine, Cairo University

\section{Introduction}

MECHANICAL ventilation is a standard component of intensive care unit management of critically ill patients and is widely used for respiratory support [1] . It is associated with numerous organsystem complications, which can significantly affect the outcome of critically ill patients [2] There are numerous mechanisms underlying the development of complications in the ventilated patient [3,4]

The influences of mechanical ventilation on kidney function generally fall under 3 categories: [5] hemodynamic changes, blood gas disturbances and biotrauma [6]. However, because effects on cardiac output and renal perfusion are insufficient to fully explain the mechanism of PPV-induced oliguria and renal dysfunction, other mechanisms have been proposed to explain these phenomena; $[7,8]$ PPV has been shown to alter a variety of neurohormonal systems including sympathetic outflow, the renin-angiotensin axis, nonosmotic vasopressin (ADH) release and atrial natriuretic peptide (ANP) production. The end result of all of these neurohormonal pathways is diminished renal blood flow, decreased GFR, and fluid retention with oliguria. $[9,10]$.

\section{The aim of study:}

To investigate the effect of positive pressure ventilation on renin and to investigate its prognostic value in relation to ICU course and outcome.

\section{Patients and Methods}

This study was conducted on 50 patients admitted to the intensive care unit (ICU of Misr University for Science and Technology Teaching Hospital) and need mechanical ventilation and 25 control 
(critically ill patients did not need mechanical ventilation) in the period from 2012 to 2015 .

\section{Patient selection:}

Patients who need mechanical ventilation on ICU admission and did not meat any of the exclusion criteria were selected into the study and they had been followed up till the day of discharge or demise. Most of patients in this study were traumatic brain injury to fulfil the exclusion criteria.

\section{Exclusion criteria:}

- Patients with chronic renal impairment.

- Patients with chronic lung disease (e.g. COPD, bronchial asthma, interstitial pulmonary fibrosis).

- Primary pulmonary hypertension

- Patients with advanced heart failure, acute myocardial infarction and hemodynamically unstable patients.

- Post-arrest patient.

- Patients with severe sepsis or septic shock.

- Patients with liver cirrhosis.

- Patients with terminal malignancy.

- Patient age <18 years old.

- Pregnant female patients.

- Patients with autoimmune disease.

Patients subdivided into two groups:

- Group I: Patients on mechanical ventilation and need high level of PEEP (10-15cm H2O), they include 25 patients

- Group II: Patients on mechanical ventilation with lower level of PEEP (5 or less) (i.e. physiological PEEP), they include 25 patients.

Control group include 25 critically ill patients admitted to ICU and did not need mechanical ventilation.

The care of patients was directed according to guidelines and was not modified by the study. Generally, the first priority was to stabilize the general condition of the patient and support them with mechanical ventilation according to their requirements.

Routine laboratory investigations were done on study day 1 and subsequently after 3 days to fulfill criteria of APACHE IV (Acute Physiology and Chronic Health evaluation).

\section{Labs specific for this study:}

Plasma renin levels were measured using ELIZA technique immediately after using mechanical ventilator and 3 days later.
Haemolytic, icteric or lipaemic samples had not been used. Samples preserved at $-20^{\circ} \mathrm{C}$ or below and stored for analysis. Frozen Samples were allowed to thaw and then the samples brought to room temperature before analysis.

\section{Principle of the test:}

The DRG Renin ELIZA kit was a solid phase enzyme-linked immunosorbent assay (ELIZA) based on the sandwich principle.

The microtiter wells was coated with monoclonal (mouse) antibody directed towards a unique antigenic site of the human active rennin molecule. An aliquot of specimen sample containing endogenous rennin was incubated in the coated well together with Assay Buffer. After incubation, unbounded components were washed off. Finally, Enzyme Conjugate, which is a monoclonal antiRenin antibody conjugated with horseradish peroxidase, was added, and after incubation, unbound enzyme conjugate was washed off.

The amount of bound peroxidase is proportional to the concentration of Renin in sample. Having added the substrate solution, the intensity of color developed is proportional to the concentration of active Renin in the specimen sample.

\section{Results}

This study was conducted on patients age ranged from $18-80$ years with a mean $(47.36 \pm 16.15)$ years. Control group age ranged from18-74 with a mean $(46.08 \pm 15.20)$ years.

There were 31 males and 19 females (male/ female ratio 1.63) in patients, while control exhibit 15 males and 10 females, (male/female ratio 1.5). There was no statistically significant difference between both groups.

\section{Clinical characteristics of enrolled patients:}

Clinical characteristic of control versus group I and group II:

In this study, group I had 6 hypertensive patients, 2 diabetic patients and 1 patient with ischemic heart disease. In group II there were 10 hypertensive patients, 3 diabetic patients and 1 patient with ischemic heart disease. In Control group 10 patients were hypertensive, 3 patients were diabetic, and 1 patient had ischemic heart disease. There was no statistically significant difference between group I and group II versus control as regard clinical characteristic. (Table 1, Fig. 1). 
Table (1): Clinical characteristic of control versus group I and group II.

\begin{tabular}{lcccc}
\hline & $\begin{array}{c}\text { Control } \\
(\mathrm{N}=25)\end{array}$ & $\begin{array}{c}\text { Group I } \\
(\mathrm{N}=25)\end{array}$ & $\begin{array}{c}\text { Group II } \\
(\mathrm{N}=25)\end{array}$ & $\begin{array}{c}p \text { - } \\
\text { value }\end{array}$ \\
\hline HTN $(\mathrm{Y} / \mathrm{N})$ & $10 / 15$ & $6 / 19$ & $10 / 15$ & 0.389 \\
DM (Y/N) & $3 / 22$ & $2 / 23$ & $3 / 22$ & 0.869 \\
IHD (Y/N) & $1 / 24$ & $1 / 24$ & $2 / 23$ & 0.767 \\
\hline
\end{tabular}

\begin{tabular}{ll}
\hline HTN : Hypertension. & N: Number. \\
DM : Diabetes mellitus. & Y: Yes. \\
IHD : Ischemic heart disease. & N: No.
\end{tabular}
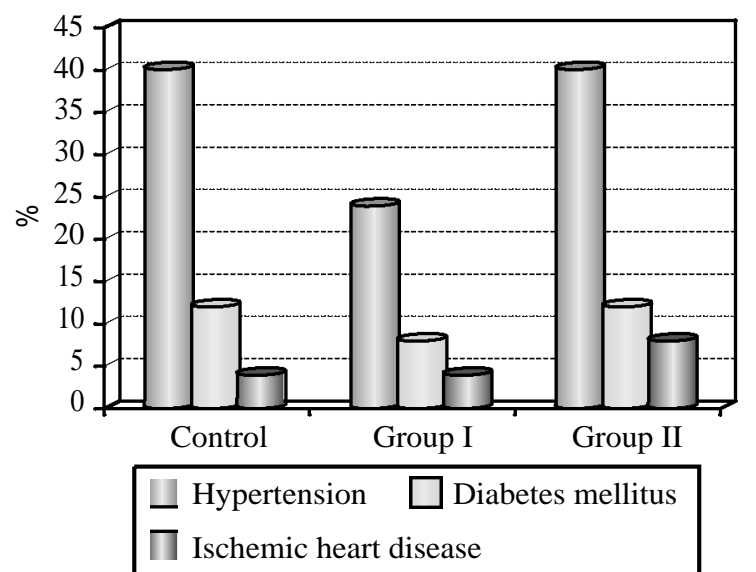

Fig. (1): Clinical characteristic of control versus group I and group II.

\section{I- Renin level in patient versus control:}

The renin 1 and 2 levels were significantly higher in group I when compare with group II and control (Table 2, Fig. 2).

Table (2): Renin level in controls versus group $1 \&$ group 2.

\begin{tabular}{llll}
\hline & $\begin{array}{c}\text { Renin 1 } \\
\text { (Mean } \pm \text { SD) } \\
\text { (Range) }\end{array}$ & $\begin{array}{c}\text { Renin 2 } \\
\text { (Mean } \pm \text { SD) } \\
\text { (Range) }\end{array}$ & $\begin{array}{c}p \text { - } \\
\text { value }\end{array}$ \\
\hline Controls (N=25) & $\begin{array}{l}22.48 \pm 20.26 \\
(2-79)\end{array}$ & $\begin{array}{l}30 \pm 24.10 \\
(3-99)\end{array}$ & 0.238 \\
Group 1 $(\mathrm{N}=25)$ & $\begin{array}{l}58.0 \pm 67.78 \\
(7-255)\end{array}$ & $\begin{array}{l}87.12 \pm 65.47 \\
(33-260)\end{array}$ & 0.128 \\
Group 2 (N=25) & $\begin{array}{l}27.72 \pm 31.96 \\
21.32 \pm 25.19\end{array}$ & 0.435 \\
& $(2-115)$ & $(3-115)$ & \\
$p$-value & 0.013 & 0.000 & \\
\hline
\end{tabular}

N: Number. SD: Standard deviation.

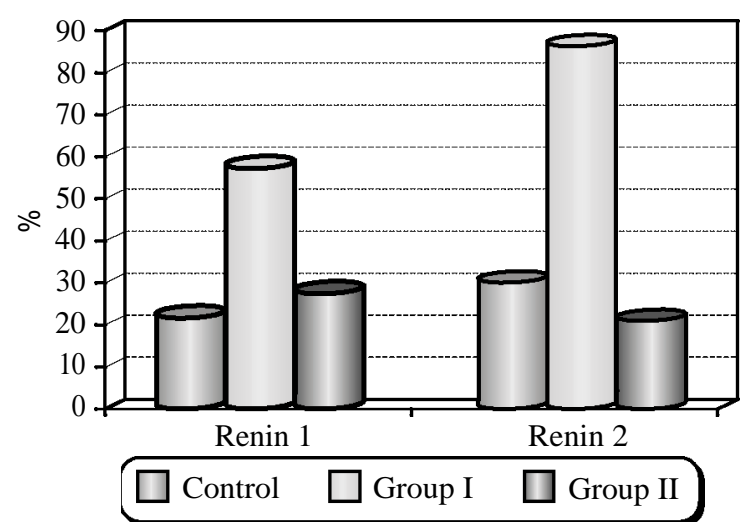

Fig. (2): Renin level in controls versus group 1 and group 2.

\section{II- Renin levels in relation to kidney function test $(K F T)$ :}

a- Renin in relation to serum Creatinine and urea levels in patients:

There was a significant positive correlation between renin with Creatinine and urea $(p=0.005)$ (Table 3).

Table (3): Renin level versus creatinine in patient.

\begin{tabular}{|c|c|c|c|c|c|c|}
\hline & Mean \pm SD & Min & Max. & Median & $r$ & $\begin{array}{c}p- \\
\text { value }\end{array}$ \\
\hline Renin 1 & $42.86 \pm 54.63$ & 2 & 255 & 17 & \multicolumn{2}{|c|}{0.2860 .045} \\
\hline $\begin{array}{c}\text { Creatinine } 1 \\
(\mathrm{mg} / \mathrm{dl})\end{array}$ & $10.82 \pm 0.34$ & 0.2 & 1.5 & 0.8 & & \\
\hline Renin 2 & $53.72 \pm 59.08$ & 3 & 260 & 120 & \multicolumn{2}{|c|}{0.3690 .005} \\
\hline$\underset{(\mathrm{mg} / \mathrm{dl})}{\text { Creatinine }} 2$ & $20.91 \pm 0.59$ & 0.1 & 2.7 & 0.8 & & \\
\hline Renin 1 & $42.86 \pm 54.63$ & 2 & 255 & 17 & \multicolumn{2}{|c|}{$0.530<0.001$} \\
\hline $\begin{array}{l}\text { Urea } 1 \\
\text { (mg/dl) }\end{array}$ & $36.92 \pm 30.38$ & 5 & 138 & 32 & & \\
\hline Renin 2 & $53.72 \pm 59.08$ & 3 & 260 & 0.494 & 0.494 & $<0.001$ \\
\hline $\begin{array}{l}\text { Urea } 2 \\
\text { (mg/dl) }\end{array}$ & $35.88 \pm 9204$ & 6 & 145 & & & \\
\hline
\end{tabular}

Min.: Minimum. Max.: Maximum. SD: Standard deviation.

1: Value at first day of mechanical ventilation.

2: Value in third day of mechanical ventilation.

b- Renin levels in relation to serum Creatinine and urea levels in control:

There was no significant correlation between renin and Creatinine or urea in control (Table 4).

Table (4): Renin levels versus creatinine in control.

\begin{tabular}{|c|c|c|c|c|c|c|}
\hline & Mean \pm SD & Min & Max. & Median & $r$ & $\begin{array}{c}p- \\
\text { value }\end{array}$ \\
\hline Renin 1 & $22.48 \pm 20.26$ & 2 & 79 & 14 & 0.118 & 0.576 \\
\hline$\underset{(\mathrm{mg} / \mathrm{dl})}{\text { Creatinine } 1}$ & $0.72 \pm 0.39$ & 0.2 & 1.52 & 0.6 & & \\
\hline Renin 2 & $30 \pm 24.10$ & 3 & 99 & 30 & -0.179 & 0.392 \\
\hline$\underset{(\mathrm{mg} / \mathrm{dl})}{\text { Creatinine } 2}$ & $0.68 \pm 0.45$ & 0.1 & 2.23 & 0.68 & & \\
\hline Renin 1 & $22.48 \pm 20.26$ & 2 & 79 & 14 & -0.052 & 0.805 \\
\hline $\begin{array}{l}\text { Urea } 1 \\
\text { (mg/dl) }\end{array}$ & $37.28 \pm 22.26$ & 6 & 91 & 40 & & \\
\hline Renin 2 & $30 \pm 24.10$ & 3 & 99 & 30 & -0.293 & 0.156 \\
\hline $\begin{array}{l}\text { Urea } 2 \\
\text { (mg/dl) }\end{array}$ & $30.88 \pm 18.95$ & 6 & 80 & 26 & & \\
\hline
\end{tabular}

Min.: Minimum. Max.: Maximum. SD: Standard deviation.

1: Value at first day of mechanical ventilation.

2: Value in third day of mechanical ventilation.

c- Renin levels in relation to urine output (UOP) in patient:

There was no significant correlation between renin and urine output in day (Table 5). 
Table (5): Renin levels versus urine output in patients.

\begin{tabular}{|c|c|c|c|c|c|c|}
\hline & Mean \pm SD & Min & Max. & Median & $r$ & $\begin{array}{c}p- \\
\text { value }\end{array}$ \\
\hline Renin 1 & $42.86 \pm 54.63$ & 2 & 255 & 17 & -0.098 & 0.500 \\
\hline $\begin{array}{l}\text { UOP } 1 \\
(\mathrm{ml} / \mathrm{h})\end{array}$ & $147.80 \pm 110.86$ & 46 & 500 & 147 & & \\
\hline Renin 2 & $53.72 \pm 59.5$ & 3 & 260 & 120 & -0.012 & 0.935 \\
\hline $\begin{array}{l}\text { UOP } 2 \\
(\mathrm{ml} / \mathrm{h})\end{array}$ & $112.86 \pm 63.86$ & 20 & 400 & 95 & & \\
\hline
\end{tabular}

Min.: Minimum. Max.: Maximum. SD: Standard deviation. UOP: Urine output. H: Hour.

1: Value at first day of mechanical ventilation.

2: Value in third day of mechanical ventilation.

d- Correlation between renin levels with GFR in patients:

There was no significant correlation between renin and GFR in day (Table 6).

Table (6): Correlation between renin levels with GFR in patients.

\begin{tabular}{llcr}
\hline & Mean \pm SD & $r$ & $p$-value \\
\hline Renin 1 & $42.86 \pm 54.63$ & -0.200 & 0.164 \\
GFR 1 & $113.56 \pm 67.04$ & & \\
Renin 2 & $53.72 \pm 59.08$ & -0.060 & 0.678 \\
GFR 2 & $119.16 \pm 75.26$ & & \\
\hline
\end{tabular}

GFR: Glomerular filtration rate. SD: Standard deviation.

1 : Value at first day of mechanical ventilation.

2: Value in third day of mechanical ventilation.

III- Renin levels in relation to severity of illness during ICU stay:

A- Correlation between renin levels with length of mechanical ventilation:

a- Renin 1 level versus length of mechanical ventilation (LOMV):

There was no significant correlation between renin and length of mechanical ventilation (Table 7).

Table (7): Renin 1 versus length of mechanical ventilation (LOMV).

\begin{tabular}{llccc}
\hline & $\begin{array}{c}\text { Renin 1 } \\
(\text { Mean } \pm \text { SD) }\end{array}$ & $\begin{array}{c}\text { LOMV (days) } \\
\text { (Mean } \pm \text { SD }\end{array}$ & $r$ & $\begin{array}{c}p- \\
\text { value }\end{array}$ \\
\hline Patients $(\mathrm{N}=50)$ & $42.86 \pm 54.63$ & $7.48 \pm 3.34$ & 0.239 & 0.095 \\
Group I (N=25) & $58 \pm 67.78$ & $8.64 \pm 3.82$ & 0.191 & 0.359 \\
Group II (N=25) & $27.72 \pm 31.96$ & $6.32 \pm 2.32$ & 0.028 & 0.894 \\
\hline
\end{tabular}

N: Number. SD: Standard deviation.

LOMV: Length of mechanical ventilation.

b- Renin 2 level versus length of mechanical ventilation (LOMV):

There was significant positive correlation between renin 2 in Patients especially in Group I with length of mechanical ventilation in patients (Table 8).
Table (8): Renin 2 versus length of mechanical ventilation (LOMV).

\begin{tabular}{lcccc}
\hline & $\begin{array}{c}\text { Renin 2 } \\
\text { (Mean } \pm \text { SD) }\end{array}$ & $\begin{array}{c}\text { LOMV (days) } \\
\text { (Mean } \pm \mathrm{SD}\end{array}$ & $r$ & $\begin{array}{c}p \text { - } \\
\text { value }\end{array}$ \\
\hline Patients (N=50) & $53.72 \pm 59.08$ & $7.8 \pm 4.65$ & 0.391 & 0.005 \\
Group I (N=25) & $87.12 \pm 65.47$ & $6.64 \pm 3.82$ & 0.407 & 0.044 \\
Group II (N=25) & $21.32 \pm 25.19$ & $6.32 \pm 2.32$ & 0.170 & 0.416 \\
\hline
\end{tabular}

$\mathrm{N}$ : Number. SD: Standard deviation.

LOMV: Length of mechanical ventilation.

B- Correlation between renin levels with need for hemodynamic support:

There was significant higher renin level in patients needed hemodynamic support than those did not need support (Table 9).

Table (9): Correlation between renin levels with need for hemodynamic support in patients.

\begin{tabular}{lccc}
\hline & $\begin{array}{c}\text { Patients need HDS } \\
(\mathrm{N}=7)(\text { Mean } \pm \mathrm{SD})\end{array}$ & $\begin{array}{c}\text { Patients not need HDS } \\
(\mathrm{N}=43)(\mathrm{mean} \pm \mathrm{SD})\end{array}$ & $\begin{array}{c}p \text { - } \\
\text { value }\end{array}$ \\
\hline Renin 1 & $134.28 \pm 88.46$ & $36.72 \pm 28.28$ & 0.018 \\
Renin 2 & $142.42 \pm 84.61$ & $43.69 \pm 39.04$ & 0.017 \\
Renin 1 & $7.75 \pm 8.88$ & $12.5 \pm 2.38$ & 0.283 \\
(controls) & & & \\
Renin 2 & $12.75 \pm 16.85$ & $11.25 \pm 2.98$ & 0.885 \\
(controls) & & & \\
\hline
\end{tabular}

N: Number. SD: Standard deviation. HDS: Hemodynamic support.

\section{C- Correlation between renin levels with length of ICU stay:}

There was no significant correlation between the length of ICU stay and renin (Table 10).

Table (10): Length of ICU stay (LOS) versus renin 1 in patients and control.

\begin{tabular}{|c|c|c|c|c|c|}
\hline & $\begin{array}{c}\text { Length of } \\
\text { ICU stay } \\
\text { (days) } \\
\text { (Mean } \pm \text { SD) }\end{array}$ & Renin 1 & Renin 2 & $r$ & $\begin{array}{c}p- \\
\text { value }\end{array}$ \\
\hline $\begin{array}{l}\text { Patients } \\
(\mathrm{N}=50)\end{array}$ & $9.3 \pm 6.2$ & $42.86 \pm 54.63$ & $53.72 \pm 59.08$ & -0.005 & 0.971 \\
\hline $\begin{array}{l}\text { Control } \\
(\mathrm{N}=25)\end{array}$ & $9.7 \pm 5.9$ & $22.48 \pm 20.26$ & $30 \pm 24.10$ & 0.315 & 0.125 \\
\hline $\begin{array}{l}\text { Group I } \\
(\mathrm{N}=25)\end{array}$ & $10.8 \pm 8.2$ & $58.0 \pm 67.78$ & $87.12 \pm 65.47$ & -0.021 & 0.921 \\
\hline $\begin{array}{l}\text { Group II } \\
(\mathrm{N}=25)\end{array}$ & I $8.7 \pm 3.9$ & $27.72 \pm 31.96$ & $21.32 \pm 25.19$ & 0.127 & 0.547 \\
\hline
\end{tabular}

N: Number. SD: Standard deviation.

\section{D- Correlation between renin levels versus APACHE IV:}

There were significant positive correlation between APACHE IV and renin only in patients (Table 11). 
Table (11): APACHE IV versus renin in patients.

\begin{tabular}{lllll}
\hline & $\begin{array}{c}\text { APACHE IV } \\
(\text { Mean } \pm \text { SD) }\end{array}$ & $\begin{array}{c}\text { Renin } \\
(\text { Mean } \pm \text { SD) }\end{array}$ & $r$ & $\begin{array}{c}p- \\
\text { value }\end{array}$ \\
\hline Day 1 (pt) & $64.62 \pm 18.30$ & $42.86 \pm 54.63$ & 0.309 & 0.029 \\
Day 3 (pt) & $63.54 \pm 17.41$ & $53.72 \pm 59.08$ & 0.403 & 0.004 \\
Day 1 (control) & $59.96 \pm 11.45$ & $22.48 \pm 20.26$ & 0.146 & 0.466 \\
Day 3 (control) & $66.76 \pm 12.12$ & $30 \pm 24.10$ & 0.025 & 0.905 \\
\hline
\end{tabular}

SD: Standard deviation.

E- Correlation between renin levels with mortality:

In patients, the non survivors exhibited significant higher levels of renin (Table 12, Fig. 3).

Table (12): Correlation between renin with mortality in patients.

\begin{tabular}{lccc}
\hline & $\begin{array}{c}\text { Survivors } \\
(\mathrm{N}=33)(66 \%) \\
(\text { Mean } \pm \mathrm{SD})\end{array}$ & $\begin{array}{c}\text { Non-survivors } \\
(\mathrm{N}=17)(34 \%) \\
(\text { mean } \pm \mathrm{SD})\end{array}$ & $\begin{array}{c}p \text { - } \\
\text { value }\end{array}$ \\
\hline Renin 1 & $29.24 \pm 25.65$ & $90.15 \pm 82.96$ & 0.017 \\
Renin 2 & $36.48 \pm 31.15$ & $102.76 \pm 85.70$ & 0.016 \\
Renin 1 (control) & $21.55 \pm 23.55$ & $29.33 \pm 20.66$ & 0.429 \\
Renin 2 (control) & $25.66 \pm 30.05$ & $32.88 \pm 33.45$ & 0.542 \\
\hline
\end{tabular}

N: Number. SD: Standard deviation.

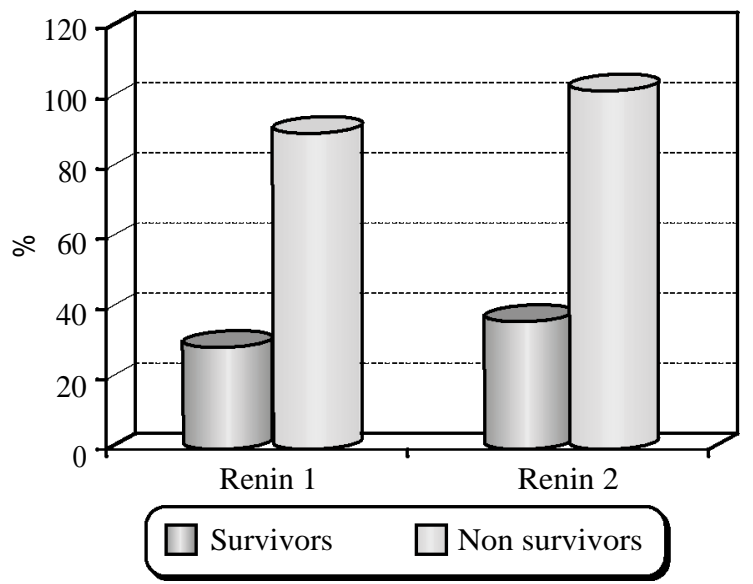

Fig. (3): Correlation between renin with mortality in patients.

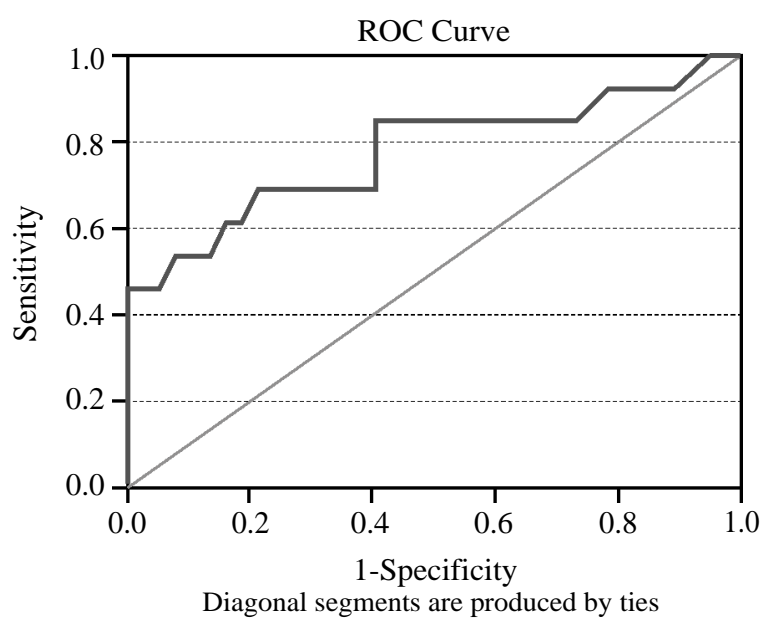

Fig. (4): Roc for mortality in all patients renin 1.
Receiver operator characteristic (ROC) curve was calculated from the use of renin 1 level in all patients as a predictor for mortality. The area under curve (AUC) for renin 1 to predict ICU mortality was 0.777 (95\% confidance interval, 0.605-0.948). The optimal cutoff value of rennin 1 level in all patients to predict ICU mortality was 41 - vith a sensitivity of $70 \%$ and specificity of $87 \%, \mathrm{PPV}=$ $76 \%$ and NPV=87\% (Fig. 4).

Receiver operator characteristic (ROC) curve was calculated from the use of renin 2 level in all patients as a predictor for mortality. The area under curve (AUC) for renin 2 to predict ICU mortality was 0.743 (95\% confidance interval, 0.560-0.926). The optimal cutoff value of renin 2 level in all patients to predict ICU mortality was 51 / with a sensitivity of $85 \%$ and specificity of $86 \%$, $\mathrm{PPV}=70 \%$ and NPP=94\% (Fig. 5).

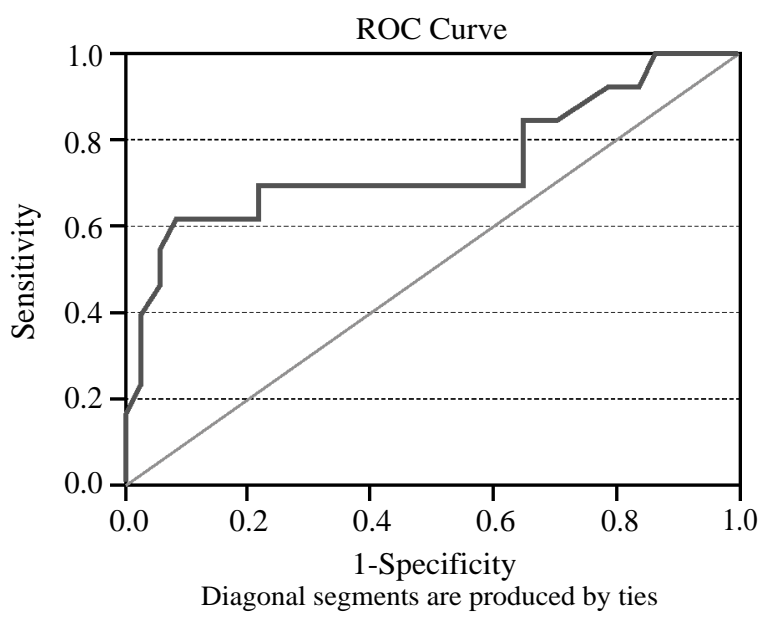

Fig. (5): Roc for mortality in all patients renin 2.

\section{Discussion}

Renin levels increased with the use mechanical ventilation and were significantly higher with higher level of PEEP. The renin $1(58.0 \pm 67.78)$ and renin $2(87.12 \pm 65.47)$ levels were significantly higher in group I when compare with group II $(27.72 \pm 31.96,21.32 \pm 25.19)$ and control $(22.48 \pm$ $20.26,30 \pm 24.10)(p=0.013$ and 0.000 respectively).

Annat G, et al. [11] measured hormonal parameters in seven intensive care patients during three consecutive 60-min periods; one of intermittent positive pressure ventilation (IPPV), one of CPPV (PEEP $10 \mathrm{~cm} \mathrm{H}_{2} \mathrm{O}$ ), and finally one of IPPV and found that Institution of PEEP led to a significant increase in plasma renin activity, plasma aldosterone.

Marius G., et al. [12] who made a study on ten male patients treated postoperatively for $60 \mathrm{~min}$ 
using five different ventilation modes, at the end of these periods, hemodynamics, urine production, fractional excretion of sodium (FESo), as well as the hormones [atrial natriuretic peptide (ANP), renin, angiotensin II, aldosterone, and antidiuretic hormone $(\mathrm{ADH})]$ were measured. They found that renin with a positive end-expiratory pressure (PEEP) of $15 \mathrm{~cm} \mathrm{H} 2 \mathrm{O}$ and an inspiration/expiration ratio (I:E) of 1:2 revealed significant increases from baseline, However aldosterone, angiotensin II, and antidiuretic hormone (ADH) levels remained within the normal range.

In addition to $\mathrm{P}$ Andrivet, et al. [13] examined the renal and hormonal responses to synthetic human ANF infusion in eight patients during mechanical ventilation with zero PEEP (ZEEP) or $10 \mathrm{~cm} \mathrm{H} 2 \mathrm{O}$ positive end-expiratory pressure (PEEP). They determined that, compared with ZEEP, MV with PEEP was associated with increase in plasma renin activity (PRA) from 4.831 .53 to 7.85 3.02ng.ml-1.h-1 (P less than 0.05). Infusion of ANF (5ng.kg-1.min-1) during PEEP markedly decreased plasma renin activity from 7.853 .02 to 4.40 1.5ng.ml-1.min-1 ( $p$ less than 0.05). In response to a 10ng.kg-1.min-1 ANF infusion.

On the other hand, JB Thorens, et al. [14] made a study to investigate the haemodynamic and endocrinological effects of noninvasive positive pressure ventilation. Measurements were performed on the fourth day, for 4 hours without noninvasive positive pressure ventilation and 4 hours with noninvasive positive pressure ventilation. They found that plasma renin activity, aldosterone and vasopressin were normal.

Also, S. Tanaka, et al. [15] measured responses during Continuous positive pressure ventilation $(\mathrm{PEEP}=12 \mathrm{mmHg})$ in 10 male subjects $(22.0 \pm 0.6$ years, $66.8 \pm 1.5 \mathrm{~kg}$ body weight). The experiments consisted of a 1-hour control, $1 \mathrm{~h}$ with Continuous positive pressure ventilation, and a $1-\mathrm{h}$ recovery period. Two blood samples were taken during each period for measurements of arginine vasopressin (AVP), plasma aldosterone, plasma renin activity, norepinephrine, and atrial natriuretic peptide. They found that neither plasma renin nor aldosterone levels were changed.

In this study, renin levels were studied in relation to kidney function test and we demonstrated that there was a significant positive correlation between renin with Creatinine and urea levels ( $p<0.005,<0.001$ respectively) only in patients. However there was no significant correlation between renin and with urine output $(p>0.005)$ or with GFR $(p>0.005)$.
Annat G, et al. [11] measured hormonal parameters in seven intensive care patients during three consecutive 60-min periods; one of intermittent positive pressure ventilation (IPPV), one of CPPV (PEEP $10 \mathrm{~cm} \mathrm{H} 2 \mathrm{O}$ ), and finally one of IPPV. During CPPV, a $15 \%$ decrease in cardiac output was observed, without alteration in arterial pressure or right atrial transmural pressure. In addition, decreases were observed in urinary output by $34 \%$, glomerular filtration rate by $19 \%$, renal blood flow by $32 \%$, sodium excretion by $33 \%$, and potassium excretion by $26 \%$. There was no change in the fractional excretion of sodium and free water.

Also, S. Tanaka, et al. [92] measured responses during Continuous positive pressure ventilation $(\mathrm{PEEP}=12 \mathrm{mmHg})$ in 10 male subjects $(22.0 \pm 0.6$ years, $66.8 \pm 1.5 \mathrm{~kg}$ body weight). The experiments consisted of a 1-hour control, 1 h with Continuous positive pressure ventilation, and a 1-h recovery period. Two blood samples were taken during each period for measurements of arginine vasopressin (AVP), plasma aldosterone, plasma renin activity, norepinephrine, and atrial natriuretic peptide and urine was collected hourly for the measurement of urine volume and electrolytes and clearances. They observed significant reduction in urine output associated with a reduction of both free water and osmolal clearances $(p<0.05)$.

Moreover Marius G, et al. [89] made a study on Ten male patients were treated postoperatively for 60 min using five different ventilation modes. At the end of these periods, hemodynamics, urine production, fractional excretion of sodium (FESo), as well as the hormones, atrial natriuretic peptide (ANP), renin, angiotensin II, aldosterone, and antidiuretic hormone (ADH), were measured in plasma. They found that urine production with a positive end-expiratory pressure (PEEP) of $15 \mathrm{~cm}$ $\mathrm{H} 2 \mathrm{O}$ and an inspiration/expiration ratio (I:E) of 1:2 revealed significant reduction from baseline.

We studied renin in relation to severity of illness as; length of mechanical ventilation, length of ICU stay, APACH IV score and mortality. This point of our study was not found in any other equivalent research.

Renin 2 was significantly correlated to length of mechanical ventilation in the patients $(53.72 \pm$ 59.08) $(p=0.005)$.

Renin levels were significant higher in patients need hemodynamic support. The mean renin 1 (134.28 \pm 88.46$)$ and renin $2(142.42 \pm 84.61)$ levels in patients need hemodynamic support versus $(36.72 \pm 28.28$ and $43.69 \pm 39.04)$ in those did not 
need hemodynamic support ( $p=0.018$ and 0.017 for renin 1 and renin 2 respectively. This correlation was more significant in group I ( $p=0.001)$.

Moreover, There were significant positive correlation between APACH IV (64.62 \pm 18.30$)$ and renin $(42.86 \pm 54.63)$ in day $1(p=0.029)$ and in day 3 (63.54 \pm 17.41 versus $53.72 \pm 59.08$ respectively) $(p=0.004)$ in patients only.

Regarding the outcome, the non survivors exhibited significant higher levels of renin $1(90.15 \pm$ $82.96)$ and renin $2(102.76 \pm 85.70)$ when compared those with survivors $(29.24 \pm 25.65$ versus $36.48 \pm$ 31.15 respectively) in patients ( $p=0.017$ and 0.016 respectively).

Receiver operator characteristic (ROC) curve was calculated from the use of renin 1, 2 levels in all patients as a predictor for mortality with an optimal cutoff value of 41,51 ith a sensitivity of $70 \%$ and specificity of $87 \%, \mathrm{PPV}=76 \%$ and $\mathrm{NPV}=87 \%$.

\section{Conclusion:}

Renin levels were increased with use mechanical ventilation and were significantly higher with higher level of PEEP. Renin levels correlated with urea and Creatinine levels and significantly correlated with APACH IV score and length of mechanical ventilation only in patients. Renin levels were significant higher in patients need hemodynamic support and in non survivors and we estimated an optimal cutoff values for renin 1 and renin 2 level of (41,51 /Lespectively) to predict ICU mortality with moderate sensitivity and specificity.

\section{References}

1- BENJAMIN D. SINGER and THOMAS C. CORBRIDGE: Basic invasive mechanical ventilation. South Med. J., 102 (12): 1238-1245, 2009.

2- O'CONNOR H.H.: "Prolonged mechanical ventilation: Are you a lumper or a splitter?". Respir Care, 56 (11): 1859-60, 2011.

3- Mechanical ventilation using non-injurious ventilation settings causes lung injury in the absence of pre-existing lung injury in healthy mice. Wolthuis, Esther K., Vlaar, Alexander P.J., Goda Choi, Joris Jth Roelofs, Juffermans, Nicole P., et al. Critical Care [NLM-MEDLINE] 13. 1, 2009.
4- ARCHAMBAULT P.M. and ST-ONGE M.: Invasive and noninvasive ventilation in the emergency department. Emerg. Med. Clin. North Am. May, 30 (2): 421-49, ix, 2012.

5- BOUFERRACHE K. and VIEILLARD-BARON A.: Acute respiratory distress syndrome, mechanical ventilation, and right ventricular function. Curr. Opin. Crit. Care, 17: 30-35, 2011

6- NAMENDYS-SILVA S.A., et al.: Pulmonary hypertension due to acute respiratory distress syndrome. Braz J. Med. Biol. Res., 47: 904-910, 2014.

7- REPESSE X., et al.: Acute cor pulmonale in ARDS. Rationale for protecting the right ventricle. Chest, 147: 259-265, 2015.

8- CHIA-TER CHAO, VIN-CENT WU and TZE-WAH KAO: Acute Kidney Injury, a Second Hit for the Prolonged Ventilated Population. International Journal of Healthcare, Insurance and Equity, Vol. 1, No 1, 2013.

9- JAY L. KOYNER and PATRICK T. MURRAY: Mechanical Ventilation and the Kidney Blood Purif, 29: 52-68, 2010.

10- LI P.K.T., BURDMANN E.A. and MEHTA R.L.: World Kidney Day 2013: Acute Kidney Injury-Global Health Alert. American journal of kidney diseases: The official journal of the National Kidney Foundation, 61 (3): 35963, 2013.

11- ANNAT G., VIALE J.P., BUI XUAN B., HADJ AISSA O., BENZONI D., VINCENT M., GHARIB C. and MOTIN J.: Effect of PEEP ventilation on renal function, plasma renin, aldosterone, neurophysins and urinary $\mathrm{ADH}$, and prostaglandins. Critical Care Medicine 37.3 March: 1046-1053, 2009.

12- MARIUS G. DEHNE1, MARKUS MEISTER2, RAINER RÖHRIG2, CHRISTIAN KATZER2 and VALESKO MANN2: Effects of inverse ratio ventilation with PEEP on kidney function. Renal Failure, 32: 411-416, 2010.

13- ANDRIVET P., ADNOT S., SANKER S., CHABRIER P.E., MACQUIN-MAVIER I., BRAQUET P. and BRUNBUISSON C.: Hormonal interactions and renal function during mechanical ventilation and ANF infusion in humans. Biochemical and Biophysical Research Communications, 371.1 (Jun 20): 50-53, 2008.

14- THORENS J.B., RITZ M., REYNARD C., RIGHETTI A., VALLOTTON M., FAVRE H., KYLE U., JOLLIET P. and CHEVROLET J.C.: Haemodynamic and endocrinological effects of noninvasive mechanical ventilation in respiratory failure. Anesthesiology, 108 (1): 46-54, 2010.

15- TANAKA S., SAGAWA S., MIKI K., CLAYBAUGH J.R. and SHIRAKI K.: Changes in muscle sympathetic nerve activity and renal function during positive-pressure breathing in humans. Critical Care Nephrology, 1055$1065,2013$. 


\section{القيمة التنبؤية للرنين في مرضى الحالات الحرجة على جهاز التنفس الصناعى مرضى الحات}

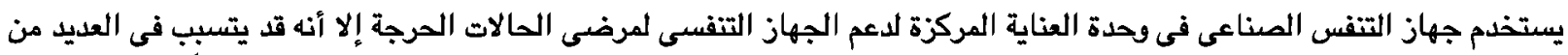
المضاعفات والتى قد تنعكس على المرضى. وقد أظهرت بعض الدران الدراسات أن التهوية الميكانيكية بالضفط الايجابى تؤثر سلباً على كمية البول وافراز الصوديوم فى البول وتصفية الكرياتينين.

وقد تقثث التهوية الميكانيكية على الكلى من خلال التأثير على بعض الهرمونات ومنها الرنين الدوستيرف و ANP و ADH والتى تتسبب

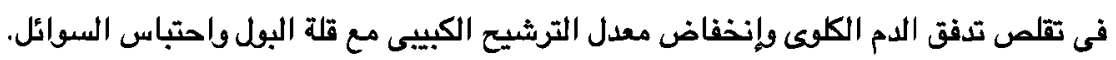

كان الهدف من هذا البحث: دراسة تأثير التهوية بالضفط الإيجابى على الرنين علاوة على إمكانية استخدام نتائع الرنين فى التتبؤ بتحسن حالة المرضى ذنى الحالات الحرجة الذين يحتاجون لجهاز التنفس الصناعى.

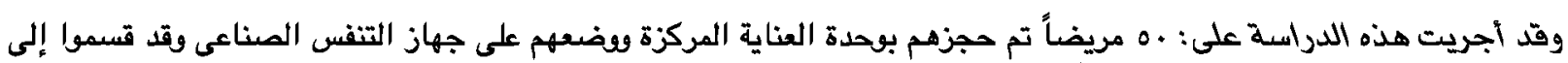

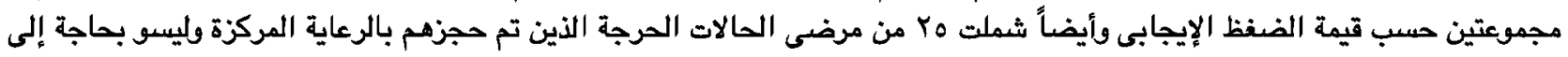
جهاز التفس الصناعى.

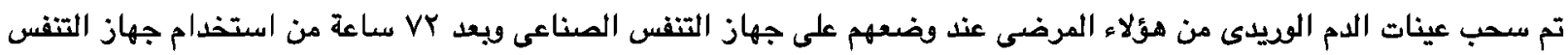
الصناعى. وقد تم قياس تركيز الرنين بإستخدام تقنيات المقايسة المناعية الشعاعية. أثبّتت النتائج: وكانت النتائج إيجابية بطريقة ملحوظة من حيث ارتفاع نسبة الرنين مع استخدام جهاز التنفس الصناعى وخاهة مع مستوى عال من الضفط الإيجابى.

وهناك صلة ذات دلالة إحصائية بين قيمة الرنين مع وظائف الكلى (اليوريا والكرياتينين) في المرضى الذين استخدموا جهاز التنفس الصناعى.

كما أن هناك ارتباط بين الرنين مع النتائج الاكلينيكية للمرضى (مدة استخدام جهاز التنفس الصناعى ومدة الا قامة فى الرعاية المركزة). وقد لوحظ ارتفاع فى نسبة الرنين فى المرضى الغير ناجين وقد تم تحديد قيمة (اع و اه ميكروجرام/لتر) لرنين ا ودنين ب أنها قيمة ذات دلالة إحصائية فى التنبئ بالوفاة. 